\section{Lawsuits and logistics tie up California's stem-cell funds}

\section{Peter Aldhous, San Francisco}

Biologists anticipating a stem-cell gold rush in California will have to wait a little longer, as a string of setbacks is slowing the state's plans to jump-start such research.

California's voters agreed last November to bankroll a \$3-billion, decade-long initiative for research on stem cells, and backers had hoped that the first research grants would appear by May of this year. But the initiative has come under mounting political and legal fire. Its leaders, facing the daunting task of building a substantial research agency from scratch, now concede that grants won't begin to go out until autumn, at the earliest.

The stem-cell ballot measure, known as Proposition 71, was drafted by Bob Klein, a property developer whose son suffers from juvenile diabetes. Klein is determined to get money into scientists' hands as quickly as possible. "We need to do our best with a responsible but aggressive schedule," he told Nature in late February.

To minimize red tape, Proposition 71 made supervision of the new agency, the California Institute for Regenerative Medicine (CIRM), the responsibility of a 29-person citizens' committee. Klein was quickly installed as committee chairman. But critics have attacked what they say is a lack of transparency in the committee's procedures, and have raised concerns about conflicts of interest. Committee members include major players in the biotechnology industry and leaders of academic institutions that are likely to apply for CIRM funding.

On 14 March, Bill Lockyer, the state attorney-general, acknowledged in a legal brief that the sale of bonds to finance the CIRM cannot begin until two lawsuits challenging its constitutional legality have been resolved. The suits have been brought by taxpayer groups and opponents of stem-cell research, and will put any grant-making on hold.

Two days later, state legislators announced moves to open up the CIRM to greater public scrutiny, and to restrict donations of human eggs for research. State senators Deborah Ortiz, a Democrat, and George Runner, a Republican, are proposing a constitutional amendment that would tighten the CIRM's conflict-of-interest rules, and force Klein's committee to hold all of its meetings in public. To pass, the amendment requires a two-thirds majority in both houses of the California legislature, and must then win support in a public ballot.

Ortiz and Runner are also proposing a three-year moratorium on women donating multiple eggs for research. The supply of human eggs is the chief limiting factor
IMAGE

UNAVAILABLE FOR COPYRIGHT REASONS

Tricky proposition: Bob Klein's plans to see research grants issued by May will have to wait.

in cloning research. "It'll be a problem if there are no egg donors," warns Lawrence Goldstein, who studies neurodegenerative diseases at the University of California, San Diego.

The proposed legislation could still allow some eggs to be donated by women who are undergoing in vitro fertilization. If so, says Evan Snyder, a stem-cell researcher at the Burnham Institute in La Jolla, it should be possible to begin cloning studies. But as Nature went to press, the precise wording of the bill had not been released.

CIRM officials say that Ortiz and Runner's planned constitutional amendment will not affect the awarding of grants. But the lawsuits could cause delay. The suits contend that the CIRM is unconstitutional because it sidesteps state laws on governance and conflicts of interest. Lockyer has asked the Supreme Court of California to deal with the suits quickly, but it is unclear when they will be resolved.

Even before these developments, the practical challenges of establishing a new granting agency from the ground up had forced the CIRM to retreat from the idea of issuing grants in May. The first grants would go to institutions to allow them to hire graduate students and postdoctoral researchers. Zach Hall, an experienced science administrator who is the CIRM's interim president, told reporters on 15 March that such grants are unlikely to be approved until after the summer, irrespective of developments in court.
Fake papers hamper plans for nuclear store at Yucca Mountain

Geoff Brumfiel, Washington

Documents relating to the safety of the proposed nuclear-waste repository at Yucca Mountain in Nevada may have been falsified, the US Department of Energy (DOE) revealed last week.

According to agency officials, a hydrologist at the US Geological Survey (USGS), who was studying how water flowed through the mountain, faked documentation on the times and dates at which certain geological samples were taken from the site.

The independent inspectors-general at both the USGS and the DOE have launched investigations, and the Nevada congressional delegation has called for a federal investigation into the issue.

The Yucca plan would see canisters of nuclear waste stored under the mountain for thousands of years. The water data are crucial because the repository's safety depends heavily on how wet it is likely to get inside, and on how long it takes for water to escape from the mountain rock into surrounding river systems.

A 1996 study by Los Alamos National Laboratory in New Mexico indicated that water takes just a few decades to flow through the mountain, raising fears that storage containers might erode and leak nuclear waste into the water table. But the DOE argues that subsequent studies and models by USGS scientists show that water moves more slowly through the mountain and that there is little threat to the local water supply.

Evidence for the falsification surfaced while the DOE was drawing up an application for a licence to store nuclear waste at the site. E-mails between the hydrologist and several colleagues dating from 1998-2000 were found that indicated he had faked documentation on the data and some computer models used to predict water flow through the mountain, says a USGS spokeswoman.

"What it means scientifically we don't yet know," says John Garrick, chairman of the Nuclear Waste Technical Review Board, which oversees the Yucca project. "But there is no doubt that it's affected public confidence in the project."

Senator Harry Reid (Democrat, Nevada), the minority leader in the Senate who opposes the construction of the repository, is calling for a full federal investigation into the alleged misdeeds. "It is abundantly clear that there is no such thing as 'sound science' at Yucca Mountain," he says. 